\title{
АНАЛІЗ ГІДРОГЕОХІМІЧНИХ УМОВ НА ДІЛЯНЦІ ПРИЛЕГЛОЇ ДО ВІДВАЛУ Ш. САМАРСЬКА (ЗАХІДНИЙ ДОНБАС)
}

\author{
Встановлені закономірності формування хімічного складу підземних вод на ділянці \\ поблизу відвалу шахти Самарська. Визначено геохімічний тип підземних вод за допомогою \\ формули М. Г. Курлова та ступінь рівноваги підземних вод з основними породоутворюючими \\ мінералами з використанням діаграм полів їх стійкості. \\ Ключові слова: підземні води, формула Курлова, тип води, діаграми рівноваги
}

Установлены закономерности формирования химического состава подземных вод на участке возле отвала ш. Самарская. Определено геоимический тип подземных вод с помощью формулы М. Г. Курлова и степень равновесия подземных вод с основными породообразующими минералами с помощью диаграмм равновесия алюмосиликатных минералов.

Ключевые слова: подземные воды, формула Курлова, тип воды, диаграммы равновесия

The regularities of formation of the chemical composition of groundwater in the area near the mine dump of Samara were installed. The geochemical type of groundwater by the formula $M$. Kurlova and degree of balance and groundwater with the main rock-forming minerals using diagrams of their fields of sustainability were defined.

Keywords: groundwater, formula Kurlova, water type, the equilibrium diagram

\section{Постановка проблеми}

Західний Донбас $\epsilon$ розвиненим гірничовидобувним регіоном України. Видобуток вугілля відбувається 31979 року закритим, відкритим та напіввідкритим способами. Забруднення підземних вод залежить від ступеня «відкритості» відпрацьованих вугільних пластів, що зумовлює інтенсивність надходження підземних вод до гірничих виробіток шахт.

Підземні води мають тісний взаємозв'язок з гірськими породами, рельєфом та іншими складовими геологічного середовища i тому швидко реагують на техногенний вплив. Гірничовидобувні роботи суттєво впливають на підземні води та викликають зміну характеру взаємодії у системі «вода - порода».

Дослідження геохімічних особливостей підземних вод необхідно для вивчення напряму зміни їх хімічного складу.

У зв'язку з цим в роботі основну увагу приділено виявленню закономірностей геохімічного стану підземних вод регіону і особливостям формування їх складу під впливом техногенних факторів у часі.

Аналіз основних випробувань та публікацій

Найбільш інтенсивно зміни геологічного середовища, а саме підземних вод відбуваються у зоні гіпергенезу. Поняття «гіпергенез» було введено А. Є. Ферсманом для визначення сукупності геохімічних процесів, що відбуваються в приповерхневій частини земної кори [1].

Основні засади гідрогеохімії та гідрогеології зони гіпергенезу, включно 3 техногенними процесами, були розроблені С. Л. Шварцевим $[2,3]$, Ф. І. Тютюновою [4] та Н. І. Плотніковим [5, 6]. 
Під час аналізу результатів власних досліджень С. Л. Шварцев ще у 1978 р. прийшов до висновку, що в умовах зони гіпергенезу система «вода - порода» має рівноважно-нерівноважний характер. Відповідно до цього положення, вода в природних умовах, незалежно від глибини залягання та швидкості руху, завжди неврівноважена 3 одними мінералами, розчинюючи їх (за участю газів та органічних речовин), але одночасно врівноважена з іншими.

У працях Тютюнової Ф. І. детально розглянуті питання міграції макро- i мікрокомпонентів у різних умовах в широкому діапазоні мінливості фізикохімічних умов. Відповідно до досліджень Ф. І.Тютюнової, метаморфізація підземних вод, що відбувається в результаті техногенного впливу, найбільш повно відображає спрямовану зміну хімічного складу і властивостей вод при вивченні гірничовидобувних регіонів.

Плотніковим Н. І. були розглянуті питання геохімічної поведінки елементів в гіпергенному циклі міграції, умови та чинники їх розсіювання і концентрації в гірських породах та підземних водах.

Завдяки роботам цих дослідників були розроблені фундаментальні теоретичні засади про механізми і фактори формування хімічного складу підземних вод, введені поняття про класи водної міграції хімічних елементів, сформовані уявлення про вертикальну i широтну гідрогеохімічну зональність, виділені провінції нормованих хімічних елементів та проведені узагальнення за хімічним складом підземних вод зони гіпергенезу.

Питаннями, пов'язаними 3 особливостями розвитку гідрогеохімічних процесів у водних об'єктах на техногенно-порушених територіях займалась Н. П. Шерстюк. Нею були вивчені особливості гідрогеохімічних процесів у техногенних та природних водних об'єктах [7].

Сучасні уявлення про систему «вода - порода» та методи хімічної термодинаміки, у тому числі комп'ютерного моделювання, відкривають великі перспективи для подальшого дослідження у цій області.

На досліджуваній території аналіз гідрогеохімічних процесів у підземних водах не виконувався і буде досліджений авторами вперше.

\section{Мета роботи}

Встановлення закономірностей формування складу підземних вод на території біля відвалу шахти Самарська (Західний Донбас) у часі.

Оцінка факторів, які впливають на зміну хімічного складу підземних вод досліджуваної ділянки.

\section{Викладення основного матеріалу}

Гідрогеологічні спостереження на полі шахти Самарська проводяться по 9-ти свердловинах, що контролюють режим першого від поверхні водоносного горизонту (рис. 1). Досліджувана ділянка розташована в заплаві р. Самара. На режим підземних вод переважний вплив мають наступні техногенні фактори: інфільтрація зі ставків-накопичувачів, підпір, підтоплення, затоплення розроблених територій та рекультивація земель. Мінералізація підземних вод на досліджуваній ділянці змінюється від 1,3 г/дм ${ }^{3}$ до 6,2 г/дм³. Підвищення мінералізації та вмісту іонів натрію та хлору спостерігається у св. 2Р біля лісового масиву «Богдановські піски». Відвал було введено в експлуатацію у 1973 р.

Основний мінералогічний склад породного відвалу шахти Самарська представлений глинистою фракцією (гідрослюди, монотерміт, монтморилоніт та біотит), в якій у незначній кількості знаходяться вуглисті уламки, польові шпати, 
мусковіт та ряд акцесорних мінералів. Сульфідні мінерали піриту та сидериту присутні у породах відвалу у допустимій кількості 1-2\%.

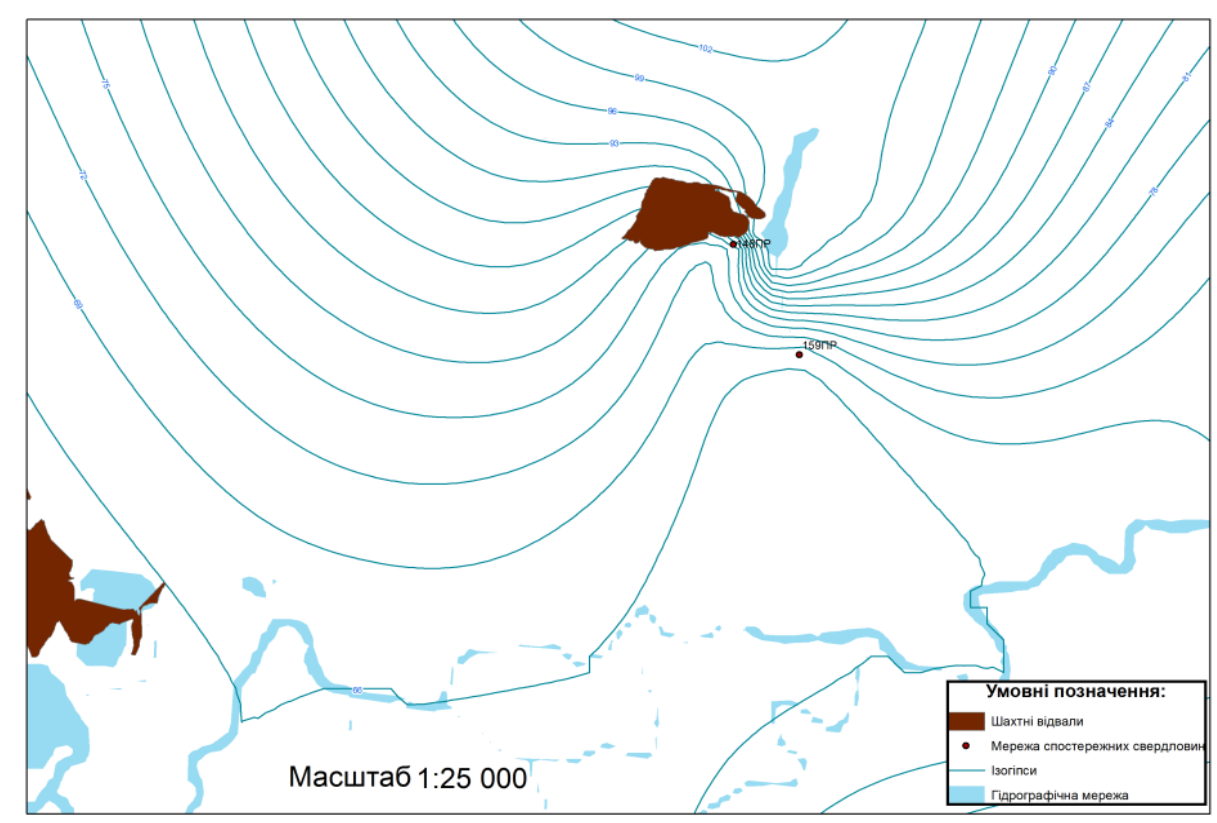

Рис 1. Карта - схема розташування відвалу ш. Самарська

Досягнення поставленої мети грунтується на даних про вміст головних іонів у підземних водах у свердловині 14925а (обладнаної на водоносний горизонт четвертинних відкладів), що знаходиться поблизу відвалу ш. Самарська за 19731974 та 2001-2003 pp.

Склад підземних вод може бути представлений у вигляді наступної формули М. Г. Курлова.

3a 1973-1974 pp.:

$$
\begin{aligned}
& \text { - } M_{0,8} \frac{\mathrm{SO}_{481} \mathrm{Cl}_{28} \mathrm{HCO}_{\mathrm{s}_{15}}}{(\mathrm{Na}+K)_{58} \mathrm{Mg}_{28} \mathrm{Ca}_{19}{ }^{\prime}} \quad \text { •(IV квартал } 1973 \text { року) } \\
& \text { - } M_{0,8} \frac{5 O_{458} \mathrm{Cl}_{25} \mathrm{HCO}_{\mathrm{3}_{17}}}{(\mathrm{Na}+K)_{61} M g_{21} \mathrm{Ca}_{18}}, \quad \text { •(II квартал } 1974 \text { року) }
\end{aligned}
$$

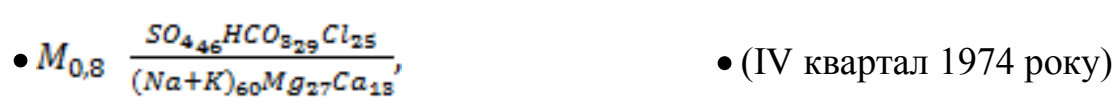

3a 2001-2003 pp.:

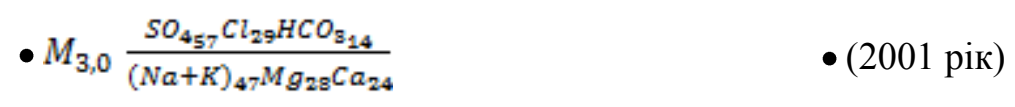




$$
\begin{aligned}
& \text { - } M_{3,3} \frac{\mathrm{SO}_{456} \mathrm{Cl}_{\mathrm{g8}} \mathrm{HCO}_{\mathrm{I}_{11}}}{(\mathrm{Na}+\mathrm{K})_{\mathrm{8g}} \mathrm{Mg}_{48} \mathrm{Ca} a_{17}} \quad \bullet(2002 \text { рік })
\end{aligned}
$$

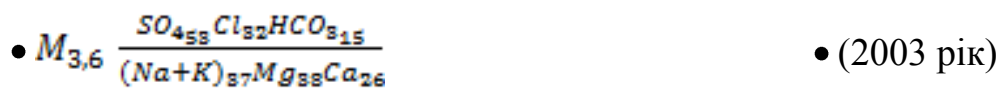

Води, що досліджуються, у 1973-1974 рр. мали гідрокабонатно-хлоридносульфатний кальцієво-магнієво-натрієвий тип води. У 2001-2003 pp. вони залишилися хлоридно-сульфатними кальцієво-магнієво-натрієвий, але. мінералізація підземних вод суттєво збільшилась (з 0,8 до 4 г/дм³). Підвищення мінералізації свідчить про вплив гірничовидобувних робіт на хімічний склад підземних вод території досліджуваної ділянки.

Також зроблено розрахунок, що дозволив оцінити за допомогою діаграм рівноваги мінералів стабільність гідрогеохімічних систем [7].

Ступінь рівноваги підземних вод 3 основними породоутворюючими мінералами була встановлена по діаграмах рівноваги алюмосилікатних мінералів (рис. 2).

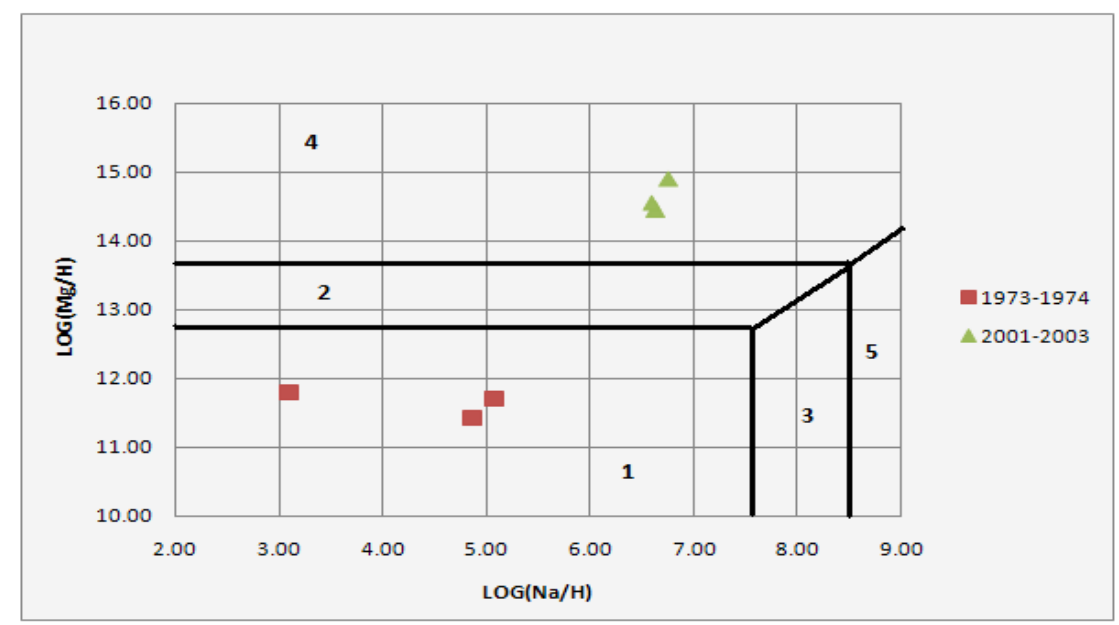

Рис. 2. Система $\mathrm{HCl}-\mathrm{H}_{2} \mathrm{O}-\mathrm{Na}_{2} \mathrm{O}-\mathrm{MgO}-\mathrm{SiO}_{2}$ при $\mathrm{t}=25^{\circ} \mathrm{C}$ та

$\lg \left[\mathrm{H}_{4} \mathrm{SiO}_{4}\right]=-3,9$ нанесеними даними аналізів проб води зі св. 14925a (1973-1974, 2001-2003 pp.)

Умовні позначення: номерами вказані поля усталеності мінералів: 1 - каолініт; 2 - Mgмонтморилоніт; 3 - Nа-монтморилоніт; 4 -хлорит; 5 - альбіт

На діаграмі рівноваги «каолініт-монтморилоніт-хлорит-альбіт» видно, що у 1973-1974 рр. підземні води знаходились у полі рівноваги з каолінітом. У 20012003 рр. рівноваги підземних вод перемістились в область хлориту. Враховуючи, що у наступному перехід у поле рівноваги 3 монтморилонітом відбувається самочинно, відповідно до реакції:

$7 \mathrm{Mg}_{5} \mathrm{Al}_{2} \mathrm{Si}_{3} \mathrm{O}_{10}(\mathrm{OH})_{8}+68 \mathrm{H}^{+}+\mathrm{H}_{4} \mathrm{SiO}_{4}{ }^{0}=6 \mathrm{Mg}_{0,16} \mathrm{Al}_{2,33} \mathrm{Si}_{3,67} \mathrm{O}_{10}(\mathrm{OH})_{2}+58 \mathrm{H}_{2} \mathrm{O}+34 \mathrm{Mg}^{2+}$ хлорит

Mg- монтморилоніт

$$
\Delta \mathrm{G}_{\text {реак }}^{0}=-2693,11 \text { кДж/моль, }
$$


можна прогнозувати, що мінералізація підземних вод та вміст іону магнію з часом збільшиться [7].

\section{Висновки}

1. 31973 р. по 2003 р. відбулось збільшення мінералізації у 4 рази (з 0,8 до 3,6 мг/дм ${ }^{3}$ при тому, що тип води не змінився.

2. Вплив гірничовидобувних робіт на формування хімічного складу підземних вод підтверджено зміною рівноваги у системі «вода - порода».

\section{Бібліографічні посилання}

1. Ферсман А. Е. Геохимия Т. 2 /А. Е. Ферсман - Л.: ОНТИ: Химтеорет, 1934. $-328 \mathrm{c}$.

2. Шварцев С. Л. Гидрогеохимия зоны гипергенеза / С. Л. Шварцев - М.: Недра, 1998. - 366 c.

3. Шварцев С. Л., Рыженко Б. Н., Алексеев В. А. и др. Геологическая эволюция и самоорганизация системы «вода-порода» Т. 2. Система «вода-порода» в условиях зоны гипергенеза / С. Л. Шварцев, Б. Н. Рыженко, В. А. Алексеев и др. Новосибирск: Изд-во СО РАН, 2007. - 289 с.

4. Тютюнова Ф. И. Физико-химические процессы в подземных водах / Ф. И. Тютюнова - М.: Наука, 1976. - 127 с.

5. Плотников Н. И. Техногенные изменения гидрогеологических условий / Н. И. Плотников - М.: Недра. 1989. - 248с.

6. Плотников Н. И., Карцев А. Л. Управление техногенными гидрогеологическими процессами как основа охраны экосистем // Тр. 27-го Междунар. геол. конгр. С-16. Гидрогеология. М.: Наука, 1984. - С. 113-118.

7. Шерстюк Н. П., Хільчевський В. К. Особливості гідрогеохімічних процесів у техногенних та природних водних об’єктах Кривбасу / Н. П. Шерстюк, В. К. Хільчевський. - Дніпропетровськ: ТОВ «Акцент ПП», 2012. - 263 с.

Надійшла до редколегії 18.03.2014 p. 